\title{
Developing Learning Media of Adaptive Sport Course in SLLB Negeri 2 Padang
}

\section{Erianti $^{*}$, Desi Novita Sari ${ }^{2}$}

1,2 Program Studi Pendidikan Jasmani Kesehatan dan Rekreasi, Fakultas Ilmu Keolahragaan, Universitas Negeri Padang Padang

A R T I C L E I N F O

Article history:

Received 20 May 2018

Received in revised

form

6 June 2018

Accepted 15 July 2018

Available online 25

August 2018

Keywords:

Development, Learning

Media, Adaptive Penjas

\section{A B S T R A C T}

In this study the problem was that the implementation of Penjasorkes learning was not maximum in SLB N 2 Padang. The implementation of Penjasorkes learning had not been success caused by a teaching strategy that was not appropriate with the condition such as the use of learning media that had not been able to provide physical education effectively and efficiently to students. So that it made the students were less creative and less motivated in doing physical activities, especially athletic material and the basic movements of running, throwing and jumping which were presented in the form of game. This research included development research that aimed to produce athletic learning media through playing with basic movements of running, jumping, and throwing for mentally retarded students at SLB $\mathrm{N} 2$ Padang. Finally, this research was expected to contribute and be useful for the development of science especially in the field of physical education, sports and health. It could be concluded that there was a significant effect of the development of learning media on the basic athletic abilities of students in SLB N 2 Padang with an increase 3.49 in the average score, from the average score of pre test 50 and the post test 53.49.

\section{Introduction}

Human resources have the potential to increase national development. One of the most influential aspects is in the field of education. Education is one of the benchmarks of a nation. Indonesia is a nation that is very concerned about education. All efforts are made by the government in advancing education. Collaboration of human resources is needed in achieving this goal.

In this case the government has determined the functions and objectives of national education as stated in RI Law No. 20 about the National Education System (2003: 11). "National Education functions to develop capabilities and form a dignified character and national civilization in order to educate the nation's life, aiming at developing potential students to become human beings who believe and fear God Almighty, have noble character, are healthy, knowledgeable, capable of being creative, independent and become a democratic and responsible citizen ". The development of human resource potential here which is the main object is the next generation of the nation. In this life there are also our generation who are born with special needs with various causes. However, the limitations of individuals do not make the spirit of education recede. Met several schools that facilitate children with special needs. Even achievements that make people proud can be obtained not only in the field of formal education, but also other skills they obtain from practicing through non-formal and informal education.

According to Hadith (2006: 34) Students with special needs are: "Students who significantly experience physical, mental, intellectual, emotional, and / or social abnormalities, so they need special education. Students can be taught and educated in exceptional schools and in ordinary schools that apply the inclusive education system. " In dealing with the various characteristics of students, an educator must also fulfill the teacher's competencies, both pedagogical, professional, personal and social competencies. 
So that it can overcome problems in accordance with the character of the students faced. Education for children with special needs is also found in Negeri 2 Padang. The subject that I will study is physical education. Based on observations and interviews of the authors with several educators in the school environment that the implementation of physical education learning at Padang State SLB 2 has not run optimally this is evidenced by the many students who are less active in the learning process. In addition, the teaching staff also does not come from the field of sports education. Maybe it causes a lack of achievement of learning objectives in adaptive physical education, especially athletic material which includes basic movements of running, throwing and jumping. Through the development of learning media in penjas, it is expected to increase the attractiveness and motivation of students in carrying out activities.

From this research, it is expected to produce a constructive action that is the solution to the problems that occur during learning Adaptive Physical Education in Padang 2. The focus of the research stated above, the research problem can be formulated, among others: 1) What is the adaptive physical education learning media for athletic material at Padang State SLB 2 which includes the basic movements of running, throwing and jumping? 2) What is the effectiveness and efficiency of adaptive physical education learning media for athletic material at Padang State SLB 2 which includes basic movements of running, throwing and jumping?

The nature of adaptive learning is ordinary learning that is modified and designed in such a way that it can be studied, carried out, and fulfills the educational needs of the learning of Extraordinary Children (children with special needs) ", Hosni (2003: 4). Motion activity greatly influences an individual's physical condition. In addition, psychological and social development will help. In the SLB there is also a physical education program. Children with special needs also need special treatment, so they can feel the physical activity / learning activities that are tailored to the character of the students. Erianti (2011: 4) suggests adaptive learning for extraordinary children is extraordinary education. Extraordinary education is learning designed to respond to or meet the needs of children with unique characteristics. In implementing adaptive learning requires the competency of creative educators and high fighting power to provide services and produce special programs. With the presence of students at school who spend more time than outside school, then this can help the education process by teachers, (Astuti, 2017: 80). Regarding children with special needs proposed by Hosni (2003: 6-8) that grouping children with special needs into two groups, namely: 1) Problems in sensorimotor, consisting of: a) Hearning disorders (hearing / hearing disorders), b) Visual impairments ( visual impairment / visual impairment), c) Physical disability. 2) Problems in learning and behavior, namely: a) Mental retardation (mental retardation / mental retardation), b) learning disability (learning disability), c) Behavior disorders (brats / tunalaras), d) Gifted and talented (gifted children ), e) Multi handicap (more than one handicap or disability). With different characteristics, the educator must also understand according to the needs of the students. One of the material in learning physical education at the Extraordinary School (SLB) is athletics where athletic numbers include running, jumping, and throwing. Lufthansa (2017: 41) suggests "Athletics is a competitive / pitted physical activity, including separate race numbers based on basic human motion abilities such as walking, running, jumping and throwing". Based on the above quote, athletics is a combination of several types of sports which can be broadly grouped into run, throw and jump. "Athletics is one of the elements of physical education and health is also a component of overall education that prioritizes physical activity and fostering a healthy life and physical, mental, social, and emotional development that are harmonious, harmonious and balanced (Widya, 2004: 56) " With the athletic material contained in the physical education subject, students will get all the components needed in education. So that there will be a balance between cognitive, affective and psychomotor aspects.

Even in athletics, a teacher can modify it and lead to exciting activities. Elements of the game, rules, facilities and infrastructure can also be adapted to athletic material which includes basic movements of running, throwing and jumping, so students become interested in physical education learning. In running movements, the footsteps that we move are when the two feet are not related to the ground. It means running when certain feet are floating in the air. Whereas jumping is a form of leap movement with the aim of obtaining a leap that is as far as or as high as possible using leg repulsion. Furthermore, lemar in athletics varies, but in physical education learning in schools children are used to being taught to throw in forms of games such as baseball ball throwing, plastic balls or rubber balls. Throwing these balls is done in the form of a game, which is done both two hands and one hand.

According to Kennedy (1994) Sumaryanti (2011: 8) suggests that generally mentally retarded children experience limitations in social behavior, self-concept, learning processes, motor coordination, communication skills, and ability to follow instructions. This condition inhibits the growth and development of children so that adaptation is needed which requires a longer process than normal children in general. The handling of this matter certainly gets treatment according to the problems faced. The limitations of the social behavior of mentally retarded children in the form of interaction or 
communication that is less interwoven is not good. But mild mentally retarded children have the ability to develop in the academic field, social adjustment and ability to work. Hosni (2003: 19-20) suggests the classification of mentally retarded children, namely: a) Mild mental retardation usually has an IQ of 70-55, b) Moderate mental retardation usually has IQ 55-40, c) Heavy mental retardation usually has an IQ of 4025 , and d) Severe and very severe mental retardation has an IQ of $<25$.

In Erianti (2017: 19), Indonesian experts use classifications namely: a) Mild Tungrahita has IQ 50 70 , b) Moderate mental retardation usually has an IQ of 30-50, c) Severe and very severe mental retardation has an IQ of $<30$. Measurement of a person's level of intelligence is measured through intelligence tests which are usually known as IQ (intelligence quotient). With an IQ test, the level of intelligence of a person can be grouped. So that problems with intelligence can be solved immediately. The physical characteristics and appearance of mentally retarded children are as follows: 1) Physical appearance is not balanced, for example the head is too small / large, 2) Can not take care of themselves, 3) Development of speech / language late, 4) No / lack of attention to environment (blank view), 5) Less movement coordination, 6) Frequent discharge of saliva (liquid) from the mouth.

Michael Johanes. H Louk, Pamuji Sukoco (2016: 4) suggests that teachers, textbooks and school environments are media more specifically. Understanding media in the teaching and learning process tends to be interpreted as a graphical tool, electronics to capture, process, and reconstruct visual information. Media in physical education in general can also be delivered through various kinds such as: magazines, newspapers, radio, television, film, video, OHP, pictures, etc. (Erianti, 2011: 46). Using the media around you will also help the learning process. All can be done with the existence of teachers who have high creativity. So, the media is not limited to the tools, but everything that makes the learning objectives happen can be achieved, it can also be said with the media. Next Giri Wiarto (2016: 14) explains "learning media is a tool to clarify teaching materials when the instructor delivers lessons." In accordance with this opinion, it can be concluded that the use of media in learning activities, such as physical education learning clearly provides great benefits for students / students. This makes it easier for students to understand the subject matter being taught because the student directly interacts with the object that is being studied, even the presence of learning media can provide good feedback for students.

If implemented in athletics, the development of learning media modification can be in the form of game models using either tools or using tools. The program and learning design were adapted to the character of mentally retarded students in Padang State SLB 2. The form of modification is given in the form of running using obstacles, throwing using obstacles, and jumping using obstacles that are interesting and cause an element of excitement for students, and can increase student motivation in the learning of physical education. Willadi Rasyid (2011: 27) says modifications in penjasorkes have four elements that must be considered by the teacher, namely: "1) modification of field size, 2) modification of equipment, 3) modification of length of game, 4) modification of game rules". In accordance with this opinion, it is clear that in physical education for students with disabilities such as mentally retarded children in SLB N 2 Padang, modifications are needed so that children in physical education are easier and more pleasant in doing what the teacher intended in learning.

\section{Method}

The main goal of this development research is to produce a product in the form of adaptive physical education learning media, especially for athletic material with the approach of various game models containing basic motion elements of running, throwing and jumping for mentally retarded children in Special Schools, so that this becomes more effective and efficient and interesting in the teaching and learning process. The place or location of this research was conducted at Padang State SLB 2. When this research was conducted for approximately 3 months, namely in June-August 2018. The targets in research and development (R \& D) of learning media on adaptive physical education learning, specifically athletic material namely basic movements of running, throwing and jumping were mentally retarded students in SLB Negeri 2 Padang. The subject taking technique applied in this study is purporsive sampling, that is, all subjects are used with certain considerations such as the limitations of the characteristics of mentally retarded students, and the limited ability of students, so that the subject is mild mental retardation students.

From the total sample of 15 people the data was taken simultaneously by 5 observers: 1) 1 adaptive penjas lecturer and 1 SLB teacher, 2) researchers, 3) 1 research assistant. For the evaluation sheet used by experts, in the form of aspects that must be assessed, the feasibility factor is the quality of the running, throwing and jumping game models. Likert scale is used as a range of evaluations ranging from "Very Suitable" to "Not Suitable" by giving a sign " $\sqrt{ }$ " in the column provided. As for numbers 1: not suitable, 2: 
Less Fit, 3: Match, 4: Very Suitable. Even this is the same for the observation sheet for students (Imam, 2015: 1922).

This development research uses descriptive analysis techniques in the form of percentages, and uses qualitative analysis to analyze data in the form of suggestions and reasons for choosing answers. The percentage results obtained will be classified and used to draw conclusions from the research data. Furthermore, to see and find out whether the learning development media can influence the basic motion abilities of running, throwing and jumping after being treated with the approach to playing with 15 products of penjas adaptive learning media, specifically athletic material, the data are analyzed using statistical formulas with data analysis techniques "t -test ".

\section{Results and Discussion}

The results of the preliminary athletic ability data analysis include the basic movements of running, throwing and jumping before being given treatment with the development of adaptive penjas learning media with a play approach, conducted on 16 mild mental retardation students, obtained the highest score of 60.73 , the lowest score 38.54 , measurement distance is 22.19 , average score 50 , median 50 and standard deviation 6.24. While the results of the analysis of the final test data after being given treatment found the highest score of 60.77 , the lowest score of 42.10 , the average score of 53.49 , the measurement distance of 18.67, the median of 51.44, and the standard deviation of 5.59. For more details, the results of the data on the influence of the development of adaptive penjas learning media through a play approach to athletic abilities on the basis of running, throwing and jumping can be seen in Table 1 .

Table 1. Frequency Distribution Data of Pre Test and Post Test Results

\begin{tabular}{clcccr}
\hline \multirow{2}{*}{ Class Interval } & \multicolumn{1}{c}{ Category } & \multicolumn{2}{c}{ Pre Test } & \multicolumn{2}{c}{ Post Test } \\
& & te frequency & Relati & $\begin{array}{c}\text { Absolu } \\
\text { ve frequency }\end{array}$ & Relati \\
& te frequency & ve frequency \\
\hline 559,14 & Excellent & 1 & 6,25 & 3 & 18,75 \\
$53,05-59,14$ & Good & 4 & 25 & 5 & 31,25 \\
$46,95-53,04$ & Sufficient & 7 & 43,75 & 6 & 37,50 \\
$40,86-46,94$ & Poor & 3 & 18,75 & 2 & 12,50 \\
$<40,86$ & Very poor & 1 & 6,25 & 0 & 0 \\
Total & & 16 & 100 & 16 & 100 \\
\hline
\end{tabular}

From the results of the preliminary test data described in Table 1 above, it is clear that, students in the excellent category only have 1 person (6.25\%) and good category, there are 4 people (25\%). Furthermore, for the medium category, there are 7 people $(43.75 \%)$, the less category is 3 people $(18.75 \%)$ and the category is very low, namely 1 person $(6.25 \%)$. Whereas for the final test it was found that students were in the excellent category, there were 3 people (18.75\%), good categories namely 5 people $(31.25 \%)$ and moderate categories which were 6 people (37.50\%). Furthermore, for the less category, there are 2 people $(12.50 \%)$ and the category is very less, no one has it. For more details, see the graph below. 


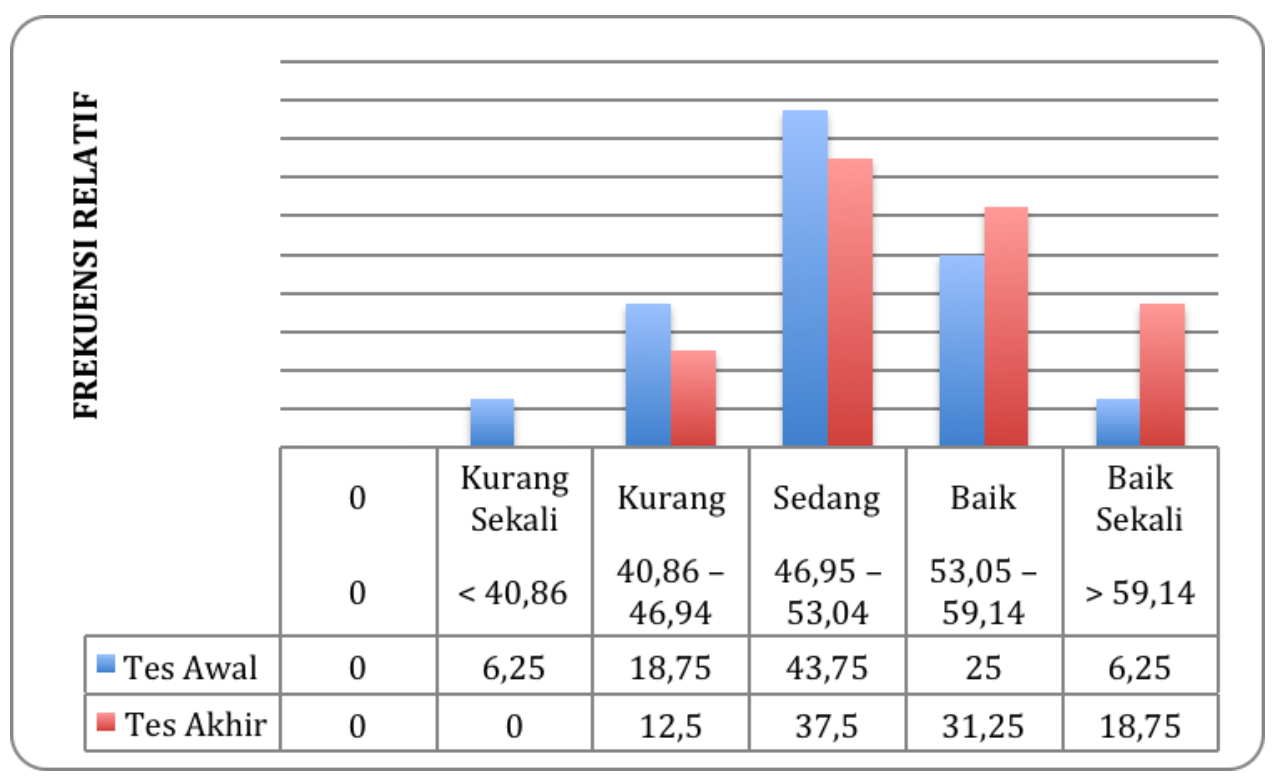

Figure 1. Graph of Pre Tests and Post Tests of Athletics Basic Motion Running, Throwing and Jumping Ability

Based on the description of the data stated earlier, the initial student test data for athletic basal abilities that are below the average group are as many as 8 people (50\%), in the average group no one has it and above the average group -rata that is as many as 8 people $(50 \%)$. Whereas for the final test data which is below the average group is 9 people (56.25\%), in the average group there is not one person who has it. While for the above group the average is as many as 7 people (43.75\%). $\alpha$ Furthermore, for the analysis of the requirements test used in this study, namely the normality test of the data to determine whether the data from the variables studied were normally distributed or not by using the Lilliefors test with a significance level of $>0.05$. The normality test of the initial test was found in the Lobservations of $0.078<$ Lt. 0.213 and the final test found Lobservation of $0.160<$ Lable of 0.213 . This means that the variables studied are from data that are normally distributed. After the analysis of the requirements test is carried out and it turns out that all the research variable data meet the requirements for further statistical testing, namely testing the hypothesis. The results of the research hypothesis testing are: there is a significant influence on the development of instructional media on the basic athletic abilities of students in Padang State 2 SLB. The statistical test used is the t-test, which is to see the effect of the calculated average in one group that is the same as the significant level of 0.05 , found tcount $=3.79>t$ table $=2.15$. Thus it can be concluded that there is a significant effect of the development of learning media on the basic athletic abilities of students at Padang State SLB 2 with an increase in the average value of 3.49, namely from the average score of the initial test of 50 and the final test to 53.49. The final result of this research is a product that is designed and judged to be able to improve the ability in adaptive physical education learning, especially athletic material which includes basic movements of running, throwing and jumping in mild mental retardation students at Padang 2 SLB. This adaptive designed and refined physical education learning media is based on the needs of mild mental retardation students in the SLB. The concept of developing learning media through a play approach is the characteristic of mentally retarded students who have limitations. According to Sumaryanti (2011: 8) in general, mentally retarded children experience limitations in social behavior, self-concept, learning processes, motor coordination, communication skills, and ability to follow instructions. This condition inhibits the growth and development of children so that adaptation is needed which requires a longer process than normal children in general. In accordance with this opinion, one way to overcome the limitations in the learning process, motor coordination, communication skills, and the ability to follow instructions that can be done through the process of learning physical education. Success in overcoming the learning process, motor coordination, communication skills, and ability to follow the instructions is done by developing physical education learning media with a play approach, specifically for athletic material, namely the basic movements of running, throwing and jumping. With a play approach or through various forms / models of games performed, children will be able to follow instructions, communicate with teachers and friends, improve motor skills or coordination, such as basic movements of running, throwing and jumping in physical education. In general, playing can be said as an 
activity or activity carried out spontaneously which can help children achieve complete development both physically, intellectually, socially, morally and emotionally. In addition, by playing children will be able to develop competence in an effort to overcome their world and develop creative activities without coercion. From playing children get fun and pleasure and children will find their weaknesses and abilities. It should also be known that one of the approaches to learning physical education in schools is how learning can make students feel happy and happy, so that learning is well designed using learning media through a play approach

Based on the data analysis of the ability of mentally retarded students in athletic material in adaptive physical education learning, which includes the basic motion of 30 meters running, throwing a ball weighing $0.5 \mathrm{~kg}$ and long jump without a start there was a significant increase and accepted the truth empirically. The increase of 3.49 is from the average score of the initial test of 50 and the final test becomes 53.49. This is due to being treated with adaptive physical education learning media with a play approach, more or less for 1.5 months (one and a half months) from July to August 2018 on Tuesdays and Thursdays, and carried out in the field of Padang 2 SLB . Indeed, in the learning process there are several forms of adaptive physical education learning media products that need to be modified. In learning physical education for mentally retarded children in the process of modification, this is necessary if the learning process given is felt by some children experiencing difficulties. As happened in the implementation of the games given there are children who are less able to accept and understand the instructions given so that it is necessary to modify the rules of the game, and even demonstrate it repeatedly until the child can understand. Thus it can be interpreted that in learning physical education, sports and health (penjasorkes) in SLB, especially for mentally retarded children important modifications. Willadi Rasyid (2011: 27) says modifications in penjasorkes have four elements that must be considered by the teacher, namely: "1) modification of field size, 2) modification of equipment, 3) modification of length of game, 4) modification of game rules". In accordance with this opinion, it is clear that in physical education for students with disabilities such as mentally retarded children in Padang State SLB 2, modifications are needed so that children in physical education are easier and more pleasant in doing what the teacher intended in learning.

In this study the development of adaptive physical education learning media, athletic material for basic movements of running, throwing and jumping through the play approach. The models of games that are presented contain basic movements of running, throwing and jumping with 15 forms of product being modified, for example, facilities and infrastructure, game rules, and duration of the game. This is done to facilitate the learning process through play play and adapted to the characteristics and abilities of mentally retarded children in responding to instructions given, as well as their physical, cognitive and social conditions. Through a variety of learning media with the approach of playing mentally retarded children to be more creative, and enthusiastic in learning physical education.

This research was supported by research conducted by Gracia Elora Mujianto (2015) with the research title Development of Adaptive Penjas Learning Model Through the Media of Rainbow Flag Games for Deaf Students of Semarang State Senior High School. The results of this study state that the development of Penjas Adaptive learning through the Rainbow Flag game media on students of the Semarang State Public Middle School Deaf School, makes the teacher have a variation or alternative in physical fitness learning to students with the Deaf Semarang SMPLB. The Rainbow Flag game makes the KBM atmosphere more lively and can be an effort to help Deaf students in some aspects of physical fitness, which ultimately has an impact on increasing student learning outcomes both from the motor, cognitive and affective domains.

\section{Conclusions and Suggestions}

Based on the data obtained, from the results of field trials and discussion of the results of the study, it can be concluded that: (1) With special adaptive penjas learning media athletic material covering basic movements of running, throwing and jumping with the approach of playing mentally retarded students can learn effectively and efficiently, (2) There is a significant effect of the development of learning media on athletic abilities for the basic movements of running, throwing and jumping students in Padang State SLB 2 with an increase in the average value of 3.49, ie from the initial score of the initial test of 50 and the final test to 53,49 . Some suggestions put forward by researchers regarding the learning media development model are: (1) The product of the development of this adaptive penjas learning media, especially athletic material including basic running, throwing and jumping with a play approach can be used as teaching media by penjasorkes teachers in SLB to mentally retarded children. (2) Penjasorkes teachers in SLB can develop this learning media for deaf and deaf children, of course adapted to the characteristics or limitations of children. (3) Before developing learning media penjasorkes teachers first 
understand well so that they can apply it in the physical education learning process. (4) Development of this adaptive penjas learning media can be continued on a broader subject, for example in other SLB.

\section{Refferences}

Ainin,Ima Kurrotun. 2011. Strategi Pembelajaran Pendidikan Jasmani Adaptif (Penelitian pada Guru Pendidikan Jasmani Adaptif Sekolah Dasar InklusifKota Surabaya). Afjl.Anakku, Volume 10, Nomor 2.

Astuti, Yuni. 2017. Pengembangan Permainan Kolaboratif Dalam Pendidikan Jasmani Dan Olahraga Di Sekolah Dasar Untuk Optimalisasi Pembentukan Karakter. Jurnal Pendidikan Jasmani dan Olahraga Volume 9 Nomor 2. September 2017.

Erianti, 2011. Pendidikan Jasmani Adaptif. Malang, Wineka Media.

Gay, LK. 1981. Educational Research: Competencies for Analysis \& Application Columbus. Charles E. Merril Publishing.

Giri Wiarto. 2016. Media Pembelajaran Dalam Pendidikan Jasmani. Yokyakarta, Glaksitas.

Hadis. 2006. Pendidikan Anak Berkebutuhan Khusus Autistik. Bandung: Alfabeta. IKAPI.

Haryoko. 2012. Pengembangan Model Pembelajaran Keterampilan Dasar Sepakbola Peserta Ekstrakurikuler Sepakbola SMP Negeri di Kota Malang, Jakarta: PPS UNJ.

Hosni. 2003. Pembelajaran Adaptif untuk Sekolah Luar Biasa. Jakarta: Depdiknas.

Imam dan Agus. 2015. Pengembangan Model Pembelajaran Gerak Dasar Lari melalui Permainan "Throw and Run" Pada Siswa Berkebutuhan Khusus (Tunarungu) di SDLB Negeri Semarang Tahun 2015. Semarang: Journal of Physical Education, Sport, Health and Recreations. 4(7)(2015)

Lufthansa. 2017. Pengembangan Model Pembelajaran Atletik Nomor Lempar untuk Anak Tunagrahita Ringan. Malang:Jurnal Keolahragaan, 5 (1), 2017, 39-49.

Mariam. (2001). Pendidikan Kebutuhan Khusus Sebuah Pengantar (terjemahan). Bandung: Program Pascasarjana UPI

Muhammad Fauzi. 2012. Model Pembelajaran Menggiring Bola Dengan Pola Pendekatan Bermain untuk Pendidikan Jasmani. Jakarta: Pascasarjana UNJ.

Mujianto, Gracia Elora. 2015. Pengembangan Model Pembelajaran Penjas Adaptif Melalui Media Permainan Rainbow Flag Pada Siswa Tunarungu SMPLB Negeri Semarang. Journal of Physical Education, Vol 2, No 1.

Rahim, Abdul. 2018. Pengembangan Model Pembelajaran Pendidikan Jasmani Adaptif Bagi Anak Berkebutuhan Khusus Di Sekolah Dasar Inklusif Kota Yogyakarta. Trihayu: Jurnal Pendidikan KeSD-an, Vol. 4, Nomor 2.

Sudjana. 1990. Penilaian Hasil Proses Belajar Mengajar. Bandung: Rosdakarya.

Sugiyono. 2010. Metode Penelitian Pendidikan. Bandung: Alfabeta.

Sumaryanti. 2011. Diseminasi Model Pembelajaran Jasmani Adaptif Untuk Optimalisasi Otak Anak Tunagrahita:Tinjauan Terapi Fisik Dan Neurosains. Yogyakarta: JURNAL KEPENDIDIKAN. Volume 40, Nomor 1, Mei 2010, hal. 29-44

Undang-undang Sistem Pendidikan Nasional No. 20 Tahun 2003 
Widya, M. D. A. 2004. Belajar berlatih gerak-gerak dasar atletik dalam bermain. Jakarta : Raja Grafindo Persada.

Willadi, Rasyid. 2011. Strategi Model Pembelajaran Penjaskesrek. Padang: Sukabina Press. 